\title{
PERANCANGAN PERKERASAN JALAN LINGKAR KOTA KABUPATEN WONOGIRI
}

\author{
Alfiani Yogaturida Isnaini \\ MSTT DTSL, Fakultas Teknik \\ Universitas Gadjah Mada \\ Yogyakarta \\ yogaturida@gmail.com
}

\author{
Latif Budi Suparma \\ MSTT DTSL, Fakultas Teknik \\ Universitas Gadjah Mada \\ Yogyakarta \\ lbsuparma@ugm.ac.id
}

\author{
Suryo Hapsoro Tri Utomo \\ MSTT DTSL, Fakultas Teknik \\ Universitas Gadjah Mada \\ Yogyakarta \\ suryohapsoro@ugm.com
}

\begin{abstract}
The city ring road of Wonogiri Regency should be constructed based on a pavement design which ensure safety, convenience, but still economical. For this reason, a road pavement design method is needed to be applied in this road design process. The MDP 2017 and AASHTO 1993 road pavement design methods are methods that are often used in Indonesia to design concrete slab for pavement. This study uses both methods to determine the thickness of the concrete slab on the pavement of the Wonogiri Regency City Ring Road. The results of this study indicate that the concrete slab thickness for pavement calculated by MDP 2017 is $31 \mathrm{~cm}$, while that calculated with AASHTO 1993 is $32.25 \mathrm{~cm}$. The difference in the thickness of the concrete plates obtained from these two methods is relatively small.
\end{abstract}

Keywords: road pavement, pavement design, concrete slab, road pavement thickness

\begin{abstract}
Abstrak
Jalan lingkar kota Kabupaten Wonogiri harus dibangun berdasarkan rancangan perkerasan jalan yang aman, nyaman, namun tetap ekonomis. Untuk itu, diperlukan suatu metode perancangan perkerasan jalan yang tepat untuk diterapkan pada proses perancangan jalan ini. Metode-metode perancangan perkerasan jalan MDP 2017 dan AASHTO 1993 merupakan metode-metode yang sering digunakan di Indonesia untuk perancangan tebal pelat beton untuk perkerasan jalan. Studi ini menggunakan kedua metode tersebut untuk menentukan tebal pelat beton pada perkerasan jalan lingkar kota Kabupaten Wonogiri. Hasil studi ini menunjukkan bahwa tebal pelat beton untuk perkerasan jalan yang dihitung dengan MDP 2017 adalah $31 \mathrm{~cm}$, sedangkan yang dihitung dengan AASHTO 1993 adalah 32,25 cm. Beda tebal pelat beton yang diperoleh dari kedua metode ini relatif kecil.
\end{abstract}

Kata-kata kunci: perkerasan jalan, perancangan perkerasan, pelat beton, tebal perkerasan jalan

\section{PENDAHULUAN}

Sebagai wilayah yang sedang berkembang, peningkatan perekonomian menjadi fokus Pemerintah Kabupaten Wonogiri. Peningkatan perekonomian ini dapat diwujudkan jika dibarengi dengan peningkatan infrastruktur, yang salah satunya adalah infrastruktur jalan. Peningkatan jalan ini dilakukan di berbagai ruas jalan utama yang memiliki peranan penting untuk peningkatan perekonomiannya, termasuk ruas jalan lingkar kota (JLK) yang akan melayani lalu lintas melalui sisi luar kota.

Sebagai jalan arteri yang harus melayani berbagai jenis kendaraan, JLK ini harus dibangun berdasarkan rancangan atau desain perkerasan jalan yang aman, nyaman, tetapi 
tetap ekonomis. Untuk itu, diperlukan suatu metode perancangan perkerasan jalan yang tepat untuk diterapkan di JLK Kabupaten Wonogiri.

Banyak metode perancangan perkerasan jalan yang biasa diterapkan di Indonesia, seperti Manual Desain Perkerasan Jalan (MDP) 2013, MDP 2017, dan AASHTO 1993. MDP 2017 sebagai manual terbaru yang diterbitkan oleh Direktorat Jenderal Bina Marga, Kementerian Pekerjaan Umum dan Perumahan Rakyat, dianggap sebagai suatu metode yang paling aktual untuk diterapkan karena menggunakan beban aktual untuk penghitungan beban lalu lintasnya. Jika pembangunan konstruksi jalan dirancang berdasarkan beban aktual, termasuk beban berlebih, yang lewat, kerusakan jalan akibat beban kendaraan dengan muatan berlebih dapat diminimalkan (Putri et al., 2014).

Penelitian ini bertujuan untuk merancang perkerasan beton pada JLK Kabupaten Wonogiri menggunakan MDP 2017. Hasilnya dibandingkan dengan hasil rancangan perkerasan jalan yang dihitung menggunakan metode AASHTO 1993. Kedua metode ini dipilih karena keduanya merupakan metode desain mekanistik empiris.

\section{Manual Desain Perkerasan Jalan 2017}

Untuk perkerasan kaku atau perkerasan/beton, manual ini dilengkapi pedoman yang diterbitkan oleh Departemen Permukiman dan Prasarana Wilayah, yaitu Perencanaan Perkerasan Jalan Beton Semen Pd T-14-2003. Berdasarkan MDP 2017 terdapat beberapa parameter dalam perancangan perkerasan kaku, yaitu umur rencana, analisis lalu lintas, CBR tanah dasar, fondasi jalan, dan mutu beton.

Umur rencana (UR) suatu jalan adalah jumlah waktu dalam satuan tahun yang dihitung sejak jalan tersebut mulai dibuka sampai saat diperlukan perbaikan berat atau rekonstruksi. Dalam melakukan analisis lalu lintas terdapat beberapa parameter, yaitu volume lalu lintas, faktor pertumbuhan lalu lintas, lalu lintas pada lajur rencana, faktor ekuivalen beban, sebaran kelompok sumbu kendaraan niaga, dan beban sumbu standar kumulatif. Data lalu lintas ini diperlukan untuk menghitung beban lalu lintas rencana yang dilayani oleh perkerasan selama umur rencana. Beban dihitung dari volume lalu lintas pada tahun survei yang selanjutnya diproyeksikan sepanjang umur rencana dengan menggunakan suatu faktor pertumbuhan lalu lintas.

Lajur rencana adalah salah satu lajur lalu lintas pada suatu ruas jalan yang menampung lalu lintas kendaraan niaga (truk dan bus) paling besar. Beban lalu lintas pada lajur rencana dinyatakan dalam kumulatif beban gandar standar (ESA) dengan memperhitungkan faktor distribusi arah (DD) dan faktor distribusi lajur kendaraan niaga (DL). Faktor ekuivalen beban atau Vehicle Damage Factor (VDF) merupakan faktor yang menyatakan perbandingan tingkat kerusakan yang disebabkan oleh satu lintasan kendaraan tertentu terhadap kerusakan yang disebabkan oleh suatu lintasan beban sumbu standar. Dalam desain perkerasan, beban lalu lintas dikonversi ke beban standar menggunakan VDF.

Beban standar kumulatif atau Cumulative Equivalent Single Axle Load (CESAL) merupakan jumlah kumulatif beban sumbu lalu lintas desain pada lajur rencana selama 
umur rencana, yang dihitung dengan menggunakan Persamaan (1) dan jumlah kelompok sumbu kendaraan niaga dihitung menggunakan Persamaan (2).

$$
\begin{aligned}
E S A_{T H-1}=\left(\Sigma L H R_{J K} \times V D F_{J K}\right) \times & 365 \times D D \times D L \times R \\
\text { Volume sumbu kendaraan niaga }= & \Sigma(\text { Jumlah kelompok sumbu } / \text { kendaraan } \times \\
& \mathrm{LHR} \times \mathrm{DD} \times \mathrm{DL} \times \mathrm{R})
\end{aligned}
$$

dengan:

$\mathrm{ESA}_{\mathrm{TH}-1}=$ Kumulatif lintasan sumbu standar ekuivalen tahun pertama;

LHR $_{\mathrm{JK}}=$ Lalu lintas harian rata-rata setiap jenis kendaraan niaga (kendaraan/hari);

VDFJK = Faktor ekuivalen beban setiap jenis kendaraan niaga;

DD $\quad$ Faktor distribusi arah;

DL $\quad=$ Faktor distribusi lajur; dan

$\mathrm{R}=$ = Faktor pengali pertumbuhan lalu lintas kumulatif.

Tiga faktor terpenting dalam desain perkerasan adalah lalu lintas, tanah dasar, dan pengaruh air. Oleh sebab itu, penentuan daya dukung tanah dasar secara akurat dan desain fondasi perkerasan merupakan syarat penting untuk menghasilkan perkerasan berkinerja baik. CBR efektif tanah dasar hendaknya tidak kurang dari 6\%. Umur rencana fondasi untuk jalan baru dan untuk pelebaran minimum 40 tahun dengan pertimbangan fondasi perkerasan tidak dapat ditingkatkan selama masa pelayanan, kecuali dengan cara rekonstruksi menyeluruh.

Kekuatan perkerasan kaku sangat dipengaruhi kekuatan pelat beton. Kekuatan beton dinyatakan dalam nilai kuat tarik lentur (flexural strength) dengan umur beton 28 hari, sedangkan tebal perkerasan beton dapat ditentukan berdasarkan kelompok sumbu kendaraan

\begin{tabular}{|c|c|c|c|c|c|}
\hline Struktur Perkerasan & $\mathrm{R} 1$ & $\mathrm{R} 2$ & R3 & $\mathrm{R} 4$ & R5 \\
\hline $\begin{array}{l}\text { Kelompok sumbu kendaraan berat } \\
\text { (overloaded) }\left(10^{6}\right)\end{array}$ & $<4,3$ & $<8,6$ & $<25,8$ & $<43$ & $<86$ \\
\hline Dowel dan bahu beton & & & $\mathrm{Ya}$ & & \\
\hline \multicolumn{6}{|c|}{ Struktur Perkerasan (mm) } \\
\hline Tebal pelat beton & 265 & 275 & 285 & 295 & 305 \\
\hline Lapis fondasi LMC & & & 100 & & \\
\hline $\begin{array}{l}\text { Lapis drainase } \\
\text { (dapat mengalir dengan baik) }\end{array}$ & & & 150 & & \\
\hline
\end{tabular}
beratnya.

Tabel 1 Tebal Pelat Beton Berdasarkan Kelompok Sumbu Kendaraan Niaga

Sumber: Direktorat Jenderal Bina Marga (2017).

\section{Metode AASHTO 1993}

Metode AASHTO 1993 merupakan salah satu metode yang prinsip perancangannya berdasarkan serviceability atau kemampuan perkerasan melayani beban selama umur rencana. Pada metode ini umur rencana perkerasan kaku umumnya 20 tahun untuk konstruksi baru. 
Parameter yang digunakan untuk mendesain perkerasan jalan meliputi analisis lalu lintas, reliability, serviceability, nilai CBR tanah dasar, mutu material beton, koefisien drainase, dan koefisien transfer beban. Data lalu lintas yang digunakan untuk perancangan tebal perkerasan meliputi jenis kendaraan, LHR, pertumbuhan lalu lintas tahunan (\%), damage factor (VDF), faktor distribusi arah, faktor distribusi lajur, dan ESAL selama umur rencana. Nilai ESAL dihitung dengan Persamaan (3).

$$
W_{18}=\sum_{N_{1}}^{N_{n}} L H R_{j} \times V D F_{j} \times D_{D} \times D_{L} \times 365
$$

dengan:

$\mathrm{W}_{18}=$ Traffic design pada lajur lalu lintas, Equivalent Single Axle Load;

$\mathrm{LHR}_{\mathrm{j}}=$ Jumlah lalu lintas harian rata-rata 2 arah untuk jenis kendaraan $\mathrm{j}$;

$\mathrm{VDF}_{\mathrm{j}}=$ Vehicle Damage Factor untuk jenis kendaraan $\mathrm{j}$;

$\mathrm{N}_{1} \quad$ = Lalu lintas pada tahun pertama jalan dibuka; dan

$\mathrm{N}_{\mathrm{n}} \quad$ = Lalu lintas pada akhir tahun rencana.

Reliability adalah probabilitas perkerasan yang direncanakan akan tetap memuaskan selama masa layannya. Penetapan angka reliability 50\%-99,99\% menurut AASHTO merupakan tingkat keandalan desain untuk mengatasi dan mengakomodasi kemungkinan melesetnya besaran-besaran desain yang digunakan.

Serviceability atau kemampuan pelayanan perkerasan, dinyatakan dalam Indeks Kemampuan Sekarang (PSI). PSI merupakan selisih indeks pelayanan awal dengan indeks pelayanan akhir. CBR digunakan untuk penentuan nilai parameter modulus reaksi tanah dasar (modulus of subgrade reaction, k). Nilai ini menunjukkan kualitas tanah dasar.

Kekuatan perkerasan kaku sangat dipengaruhi oleh karakteristik beton yang digunakan. Nilai kuat lentur $\left(\mathrm{S}_{\mathrm{c}}{ }^{\prime}\right)$ dan kuat tekan $\left(\mathrm{f}_{\mathrm{c}}{ }^{\prime}\right)$ material beton tersebut merupakan parameter penting dalam perancangan tebal perkerasan. Selain kuat lentur dan kuat tekan, kekuatan beton juga ditentukan oleh nilai modulus beton $\left(E_{c}\right)$.

Koefisien drainase merupakan faktor koreksi terhadap kinerja perkerasan akibat kondisi drainase yang kurang baik. Koefisien drainase ditentukan oleh 2 variabel, yaitu kualitas drainase dan persentase struktur perkerasan yang terkena air sampai tingkat mendekati jenuh air dalam satu tahun. Koefisien transfer beban (J) merupakan koefisien yang memperhitungkan kemampuan perkerasan beton mentransfer beban yang melintas di atas sambungan atau retakan.

Semua parameter tersebut dimasukkan ke dalam Persamaan (4) untuk mendapatkan tebal pelat beton yang dirancang.

$$
\begin{aligned}
\log _{10} W_{18}= & Z_{R} S_{o}+7,35 \log _{10}(D+1)-0,06+\frac{\log _{10}\left(\frac{\Delta P S I}{4,5-1,5}\right)}{1+\frac{1,624 \times 10^{7}}{(D+1)^{8,46}}}+ \\
& \left(4,22-0,32 P_{t}\right) \times \log _{10} \frac{S_{c}^{\prime} C_{d} \times\left[D^{0,75}-1,132\right]}{215,63 \times J \times\left[D^{0,75}-\frac{18,42}{\left(E_{c} / k\right)^{0,25}}\right]}
\end{aligned}
$$


dengan:

$\mathrm{W}_{18}=$ lalu lintas rancangan (ESAL);

$\mathrm{ZR}$ = deviasi standar normal;

So = standar deviasi keseluruhan;

$\Delta \mathrm{PSI}=$ kehilangan kemampuan pelayanan $=\mathrm{Po}-\mathrm{Pt}$;

P0 = indeks kemampuan pelayanan awal;

$\mathrm{Pt}=$ indeks kemampuan pelayanan akhir;

$\mathrm{Sc}^{\prime}=$ kuat lentur beton (PSI);

$\mathrm{Cd}=$ koefisien drainase;

$\mathrm{J}=$ koefisien transfer beban;

$\mathrm{Ec}=$ modulus elastisitas beton (PSI); dan

$\mathrm{k} \quad=$ modulus reaksi tanah dasar (PSI).

\section{METODOLOGI PENELITIAN}

Objek perancangan perkerasan jalan beton pada studi ini adalah JLK Kabupaten Wonogiri. Panjang segmen adalah 5.500 m, dari Sta 7+700 sampai dengan Sta 13+200.

Studi diawali dengan kajian pustaka mengenai perancangan perkerasan jalan beton dengan berbagai metode. Selanjutnya, ditentukan metode yang akan digunakan untuk merancang, yaitu MDP 2017 dan AASHTO 1993. Data yang diperlukan dikumpulkan untuk digunakan dalam desain perkerasan jalan beton dengan kedua metode tersebut.

\section{Pengumpulan Data}

Studi ini dilaksanakan dengan cara menghitung desain perkerasan jalan berdasarkan LHR Tahun 2017. Data mengenai jalan eksisting, seperti lebar jalan, tebal perkerasan, fondasi, tanah dasar, dan mutu beton pada segmen yang sudah terbangun didapat dari Dinas Pekerjaan Umum Kabupaten Wonogiri. Data LHR yang digunakan adalah data tahun 2017 yang diperoleh dari Dinas Bina Marga, Pemerintah Provinsi Jawa Tengah.

\section{Alur Analisis Data}

Prosedur desain perkerasan kaku menurut MDP 2017 meliputi penentuan umur rencana perkerasan, penentuan volume kelompok sumbu kendaraan niaga, penentuan struktur fondasi jalan, penentuan daya dukung efektif tanah dasar, dan penentuan struktur lapisan perkerasan berupa tebal pelat betonnya. Penentuan detail desain yang berupa tebal pelat beton yang direncanakan pada perkerasan kaku mengikuti pedoman Perencanaan Perkerasan Jalan Beton Semen Pd T-14-2003.

Perancangan dengan metode AASHTO 1993 membutuhkan input data yang akan menentukan beberapa nilai parameter yang akan digunakan dalam penentuan desain perkerasannya. Umur rencana, faktor distribusi arah, faktor distribusi lajur, LHR pada tahun dibuka, pertumbuhan lalu lintas tahunan, dan VDF digunakan untuk menghitung 
parameter ESAL. Parameter lainya adalah deviasi normal standar, deviasi standar, serviceability loss, modulus reaksi tanah dasar, modulus elastisitas beton, kuat lentur beton, koefisien drainase, serta koefisien transfer beban. Selanjutnya semua parameter dimasukkan ke Persamaan (4) dan dicoba memasukkan tebal tertentu sampai didapat tebal pelat yang memenuhi persamaan.

\section{HASIL DAN ANALISIS}

\section{Metode MDP 2017}

Menurut MDP 2017, perkerasan kaku umumnya memiliki discounted lifecycle cost rendah apabila diterapkan pada jalan dengan beban lalu lintas lebih besar daripada 30 juta ESA4. Jalan Lingkar Kota Kabupaten Wonogiri ini memiliki beban lalu lintas sebesar 113 juta ESA4 dalam 40 tahun (Tabel 2), sehingga dapat digunakan jenis perkerasan kaku.

Tabel 2 Nilai ESA4 Selama Umur Rencana 40 Tahun

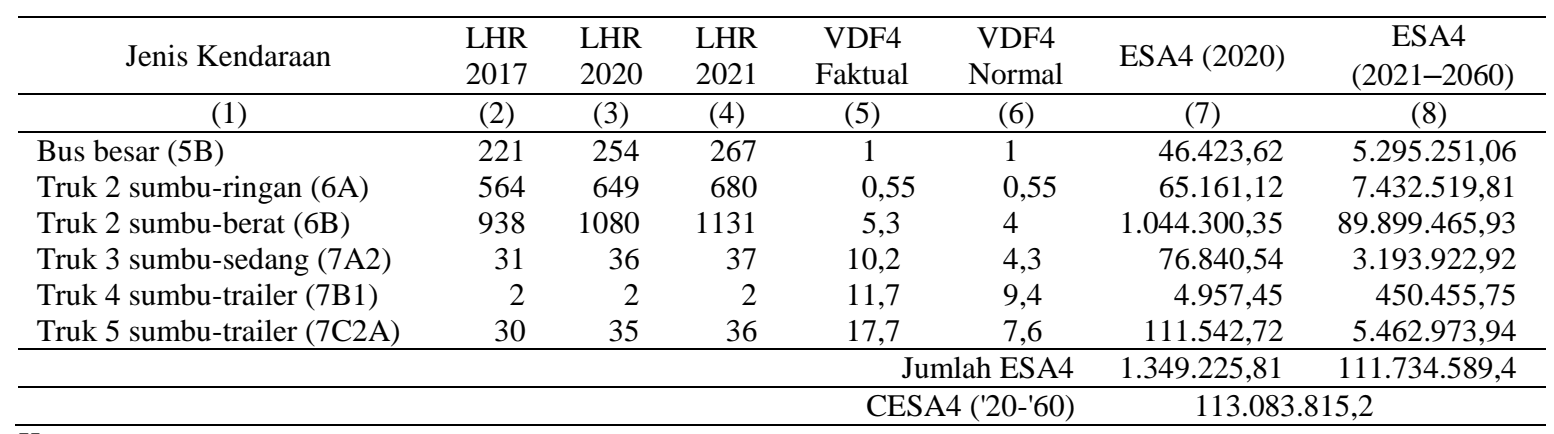

Keterangan:

(3) $=(2) \times(1+0,048)^{3}$;

$(4)=(2) \times(1+0,048)^{4}$;

(5) dan (6) diperoleh dari MDP 2017;

$(7)=(3) \times(5) \times 365 \times \mathrm{DD} \times \mathrm{DL} \times \mathrm{R}_{(2020)}$ dimana $\mathrm{DD}=0,5 ; \mathrm{DL}=1 ; \mathrm{R}_{(2020)}=\frac{(1+0,01 \times 4.8)^{1}-1}{0,01 \times 4,8}=1$;

$(8)=(4) \times(6) \times 365 \times \mathrm{DD} \times \mathrm{DL} \times \mathrm{R}_{(2021-2060)}$; di mana $\mathrm{R}_{(2021-2060)}=\frac{(1+0,01 \times 4.8)^{1}-1}{0,01 \times 4,8}=108,84$

Nilai jumlah kelompok sumbu kendaraan berat merupakan dasar untuk memilih tebal pelat beton rencana. Perhitungan jumlah kelompok sumbu kendaraan berat ini dapat dilihat pada Tabel 3.

Tabel 3 Jumlah Kelompok Sumbu Kendaraan Berat

\begin{tabular}{|c|c|c|c|c|}
\hline Jenis Kendaraan & $\begin{array}{c}\text { Jumlah Kelompok } \\
\text { Sumbu Per } \\
\text { Kendaraan }\end{array}$ & $\begin{array}{l}\text { LHR } \\
2020\end{array}$ & $\begin{array}{c}\text { Kelompok } \\
\text { Sumbu } 2020\end{array}$ & $\begin{array}{c}\text { Jumlah Kelompok } \\
\text { Sumbu } \\
2020-2060\end{array}$ \\
\hline (1) & $(2)$ & (3) & (4) & $(5)$ \\
\hline Bus besar & 2 & 254 & 509 & $10.683 .349,35$ \\
\hline Truk 2 sumbu-ringan & 2 & 649 & 1298 & $27.264 .294,28$ \\
\hline Truk 2 sumbu-berat & 2 & 1080 & 2159 & $45.343 .808,57$ \\
\hline Truk 3 sumbu-berat & 2 & 36 & 71 & $1.498 .569,37$ \\
\hline Truk 4 sumbu-trailer & 3 & 2 & 7 & $145.022,84$ \\
\hline Truk 5 sumbu-trailer & 3 & 35 & 104 & $2.175 .342,63$ \\
\hline \multicolumn{4}{|c|}{ pok sumbu kendaraan berat 2020-2060 } & $87.110 .387,04$ \\
\hline
\end{tabular}

Keterangan: $(4)=(2) \times(3) ;(5)=(4) \times D_{D} \times D_{L} \times R_{40} \times 365$. 
Terkait desain fondasi jalan, berdasarkan Tabel 1, untuk perkerasan yang harus menopang kumulatif sumbu kendaraan berat sebesar $87 \times 10^{6}$ perlu diberi lapis Lean Mix Concrete (LMC) setebal $100 \mathrm{~mm}$ dengan mutu beton f'c $10 \mathrm{MPa}$, serta lapis fondasi yang tersusun menggunakan agregat kelas A setebal $150 \mathrm{~mm}$. Karena CBR yang direncanakan sebesar 6\%, berdasarkan grafik pada Pd T-14-2003 diperoleh CBR tanah dasar efektif sebesar $40 \%$.

Beton yang digunakan adalah beton kelas K 300, dengan kuat tarik lentur $\left(\mathrm{f}_{\mathrm{cr}}\right) 40$ $\mathrm{kg} / \mathrm{cm}^{2}$. Berdasarkan besarnya jumlah kelompok sumbu kendaraan berat, yaitu $87 \times 10^{6}$, perkerasan jalan ini sedikit di atas struktur perkerasan R5 $\left(<86 \times 10^{6}\right)$. Oleh karena itu, pelat betonnya dirancang setebal $310 \mathrm{~mm}$. Selanjutnya tebal tersebut dianalisis terhadap fatik dan erosinya, seperti yang ada pada Tabel 4. Perhitungan repetisi yang terjadi dapat dilihat pada Tabel 5 dan analisis fatik dan erosinya seperti pada Tabel 6.

Tabel 4 Hasil Penghitungan Proporsi Beban

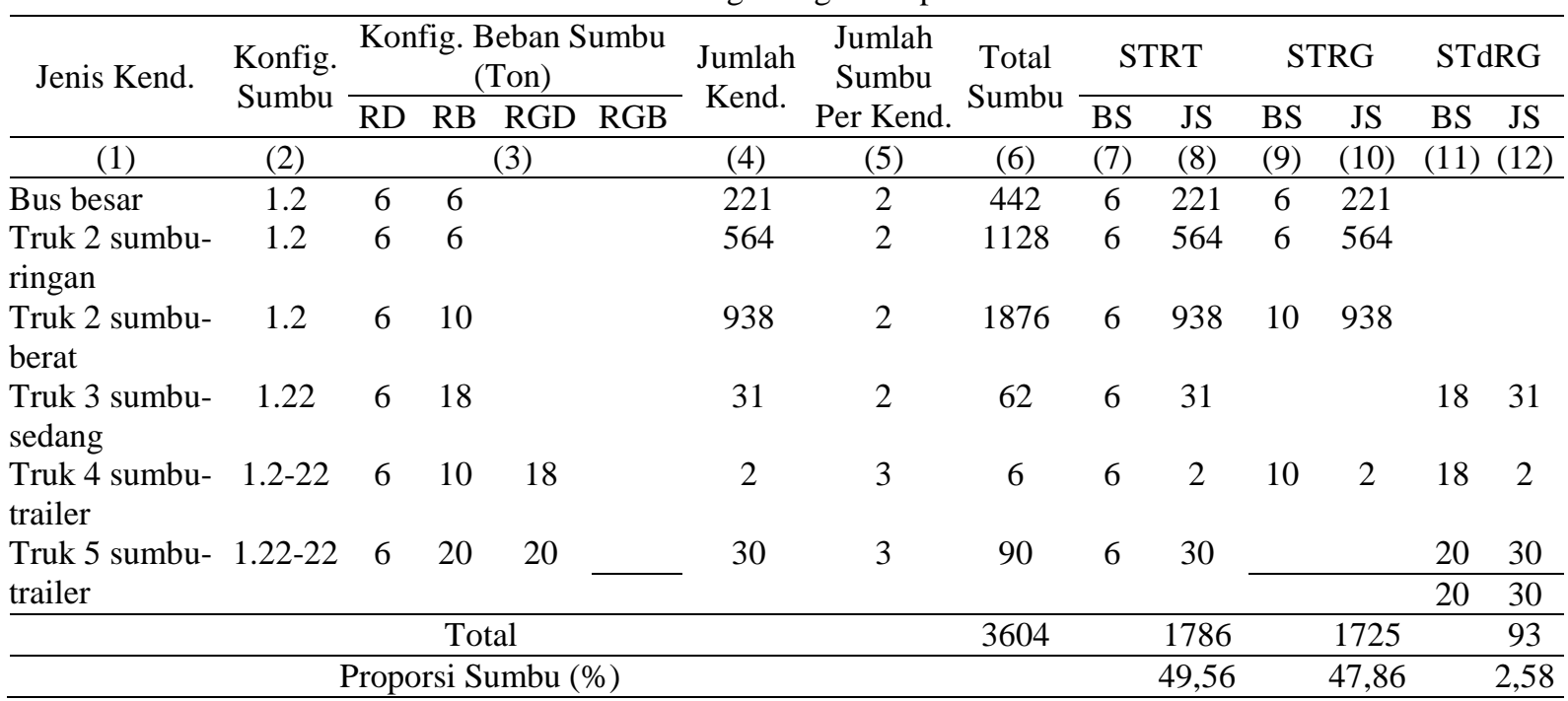

Keterangan:

$(6)=(4) \times(5)$; Proporsi sumbu $=\frac{\text { Jumlah sumbu di setiap jenis sumbu }}{\text { Total sumbu }} ; \mathrm{RD}=$ Roda depan; RB = Roda belakang; RGD = Roda gandeng depan; RGB = Roda gandeng belakang; STRT = Sumbu tunggal roda tunggal; STRG $=$ Sumbu tunggal roda ganda; $\mathrm{STdRG}=$ Sumbu tandem roda ganda; $\mathrm{BS}=$ Beban sumbu (Ton); dan JS = Jumlah sumbu (Buah).

\section{Metode AASHTO 1993}

Perancangan dengan menggunakan metode AASHTO ini diawali dengan penghitungan traffic design-nya. Kemudian dilanjutkan dengan analisis probabilitas, yaitu bagaimana jalan tersebut nantinya dapat berfungsi dengan baik selama masa layan, sampai dengan tahap akhir, yaitu penentuan tebal perkerasannya.

ESAL dihitung dengan Persamaan (3) dan hasilnya terlihat pada Tabel 7. Data LHR 2017-2056 diperoleh dengan memproyeksikan data LHR tahun 2017 dengan faktor pertumbuhan sebesar 4,8\%. Nilai VDF yang digunakan sama dengan nilai VDF yang dipakai pada metode MDP 2017. Karena JLK ini hanya terdiri atas 1 lajur di setiap arahnya, faktor distribusi lajurnya adalah 1. Nilai faktor distribusi arah (DD) diambil sebesar 
0,5 karena data LHR diperoleh dari survei kendaraan yang dilakukan hanya pada satu arah. Kemudian semua parameter dimasukkan ke Persamaan (4) untuk menghitung tebal pelat beton, yang hasilnya dirangkum pada Tabel 8 .

Tabel 5 Repetisi yang Terjadi

\begin{tabular}{|c|c|c|c|c|c|c|}
\hline Jenis Sumbu & Beban Sumbu & $\begin{array}{l}\text { Jumlah } \\
\text { Sumbu }\end{array}$ & Proporsi Beban & Proporsi Sumbu & $\begin{array}{c}\text { Lalu Lintas } \\
\text { Rencana }\end{array}$ & Repetisi \\
\hline (1) & (2) & (3) & (4) & (5) & (6) & (7) \\
\hline STRT & 6 & 1.786 & 1 & $49,56 \%$ & 87.110 .387 & 43.168 .466 \\
\hline \multicolumn{2}{|c|}{ Total } & 1.786 & 1 & & & \\
\hline \multirow[t]{2}{*}{ STRG } & 10 & 940 & 0,54 & $47,86 \%$ & 87.110 .387 & 22.720 .245 \\
\hline & 6 & 785 & 0,46 & & & 18.973 .822 \\
\hline \multicolumn{2}{|c|}{ Total } & 1725 & 1 & & & \\
\hline \multirow[t]{2}{*}{ STdRG } & 20 & 60 & 0,65 & $2,58 \%$ & 87.110 .387 & 1.450 .228 \\
\hline & 18 & 33 & 0,35 & & & 797.626 \\
\hline \multicolumn{2}{|c|}{ Total } & 93 & 1 & & & \\
\hline \multicolumn{6}{|c|}{ Kumulatif } & 87.110 .387 \\
\hline
\end{tabular}

Keterangan:

(4) $=\frac{(3)}{\text { Total tiap jenis sumbu }} \times 100 \%$;

$(7)=(4) \times(5) \times(6)$.

Tabel 6 Analisis Fatik dan Erosi

\begin{tabular}{|c|c|c|c|c|c|c|c|c|c|c|}
\hline \multirow{2}{*}{$\begin{array}{c}\text { Jenis } \\
\text { Sumbu }\end{array}$} & \multirow{2}{*}{$\begin{array}{c}\text { Beban } \\
\text { Sumbu } \\
(\mathrm{kN})\end{array}$} & \multirow{2}{*}{$\begin{array}{c}\text { Beban } \\
\text { Rencana } \\
\text { per Roda } \\
(\mathrm{kN})\end{array}$} & \multirow{2}{*}{ Repetisi } & \multicolumn{3}{|c|}{$\begin{array}{l}\text { Faktor Tegangan dan } \\
\text { Erosi }\end{array}$} & \multicolumn{2}{|c|}{ Analisis Fatik } & \multicolumn{2}{|c|}{ Analisis Erosi } \\
\hline & & & & $\mathrm{TE}$ & $\mathrm{FE}$ & FRT & $\begin{array}{l}\text { Repetisi } \\
\text { Izin }\end{array}$ & $\begin{array}{l}\text { Persen } \\
\text { Rusak }\end{array}$ & $\begin{array}{l}\text { Repetisi } \\
\text { Izin }\end{array}$ & $\begin{array}{l}\text { Persen } \\
\text { Rusak }\end{array}$ \\
\hline$(1)$ & $(2)$ & (3) & (4) & (5) & (6) & (7) & $(8)$ & $(9)$ & (10) & $(11)$ \\
\hline STRT & 60 & 30 & 43.168 .466 & 0,43 & 1,2 & 0,11 & TT & 0 & $\mathrm{TT}$ & 0 \\
\hline \multirow{2}{*}{ STRG } & 100 & 25 & 22.720 .245 & \multirow{2}{*}{0,68} & \multirow{2}{*}{1,81} & \multirow{2}{*}{0,17} & TT & 0 & $\mathrm{TT}$ & 0 \\
\hline & 60 & 15 & 18.973 .822 & & & & $\mathrm{TT}$ & 0 & $\mathrm{TT}$ & 0 \\
\hline \multirow{2}{*}{ STdRG } & 200 & 25 & 1.450 .228 & \multirow{2}{*}{0,6} & \multirow{2}{*}{1,95} & \multirow{2}{*}{0,15} & TT & 0 & $\mathrm{TT}$ & 0 \\
\hline & 180 & 22,5 & 797.626 & & & & $\mathrm{TT}$ & 0 & TT & 0 \\
\hline & & & Total & & & & & 0 & & 0 \\
\hline
\end{tabular}

Keterangan:

(3) $=(2)$ / jumlah roda tiap sumbu;

$(7)=(5) / f_{\text {cr }} ;(9)=(4) /(8) \times 100 \%$;

$(11)=(4) /(10) \times 100 \%$;

(5), (6), (8), dan (10) (dari Pd T-14-2003);

$\mathrm{TE}=$ Tegangan ekuivalen $; \mathrm{FE}=$ Faktor erosi $; \mathrm{FRT}=$ Faktor rasio tegangan $; \mathrm{TT}=$ Tidak terhingga

Tabel 7 Hasil Penghitungan ESAL

\begin{tabular}{|c|c|c|c|c|c|c|}
\hline Jenis Kendaraan & $\mathrm{LHR}_{2017-2056}$ & VDF & $\mathrm{LHR}_{2017-2056} \times \mathrm{VDF}$ & $\mathrm{DD}$ & $\mathrm{DL}$ & $\mathrm{W}_{18}$ \\
\hline$(1)$ & $(2)$ & (3) & (4) & $(5)$ & (6) & $(7)$ \\
\hline Bus besar & 25429 & 1 & 25429 & \multirow{7}{*}{0,5} & \multirow{7}{*}{1} & \multirow{7}{*}{133.835 .859} \\
\hline Truk 2 sumbu-ringan & 64896 & 0,55 & 35693 & & & \\
\hline Truk 2 sumbu-berat & 107930 & 5,3 & 572028 & & & \\
\hline Truk 3 sumbu-sedang & 3567 & 10,2 & 36383 & & & \\
\hline Truk 4 sumbu-trailer & 230 & 11,8 & 2716 & & & \\
\hline Truk 5 sumbu-trailer & 3452 & 17,7 & 61099 & & & \\
\hline \multicolumn{3}{|c|}{ Jumlah } & 733347 & & & \\
\hline
\end{tabular}

Keterangan:
(4) $=(2) \times(3)$;
$(7)=\Sigma(4) \times(5) \times(6) \times 365$ 
Tabel 8 Parameter-Parameter untuk Penghitungan Tebal Pelat Beton

\begin{tabular}{lclr}
\hline \multicolumn{1}{c}{ Parameter } & Nilai & \multicolumn{1}{c}{ Parameter } & Nilai \\
\hline Umur rencana (UR) & 40 tahun & Kuat tekan beton (f'c) & $3.540,78$ Psi \\
ESAL (W18) & 133.835 .859 & Modulus elastisitas beton (Ec) & $3.391 .753,86$ Psi \\
Reliability (R) & $85 \%$ & Kuat lentur (S'c) & 568,8 Psi \\
Standar normal deviasi (ZR) & $-1,037$ & CBR & $6 \%$ \\
Standar deviasi (S0) & 0,35 & Modulus reaksi tanah dasar (k) & 150 Psi \\
Initial serviceability index (P0) & 4,5 & Koefisien drainase (Cd) & 1,18 \\
Terminal serviceability index (PT) & 2,5 & Koefisien transfer beban (J) & 2,6 \\
Serviceability loss $(\Delta \mathrm{PSI})$ & 2 & & \\
\hline
\end{tabular}

Dengan melakukan trial nilai D, didapatkan tebal perkerasan beton 12,7 inci atau sama dengan $32,25 \mathrm{~cm}$ :

$$
\begin{aligned}
\log _{10} 133.835 .859= & -1,037 \cdot 0,35+7,35 \log _{10}(D+1)-0,06+\frac{\log _{10}\left(\frac{2}{4,5-1,5}\right)}{1+\frac{1,624 \times 10^{7}}{(D+1)^{8,46}}}+ \\
& (4,22-0,32 \cdot 2,5) \times \log _{10} \frac{568,8 \cdot 1,18 \times\left[D^{0,75}-1,132\right]}{215,63 \times 2,6 \times\left[D^{0,75}-\frac{18,42}{(3.391 .753,86 / 150)^{0,25}}\right]}
\end{aligned}
$$

\section{Pembahasan}

Dari hasil perhitungan yang telah dilakukan, diperoleh nilai tebal pelat beton yang berbeda. Berdasarkan MDP 2017, diperoleh tebal pelat beton sebesar $31 \mathrm{~cm}$, sedangkan dengan menggunakan AASHTO 1993 diperoleh tebal sebesar 32,25 cm. Hasil perhitungan ini disajikan pada Gambar 1. Terdapat perbedaan tebal sebesar $1,25 \mathrm{~cm}$ atau $4 \%$ hasil dari metode AASHTO 1993 terhadap hasil metode MDP 2017. Hal ini terjadi dikarenakan adanya perbedaan prinsip perancangan pada kedua metode ini dan perbedaan parameter input yang digunakan.

Pada Manual Desain Perkerasan 2017, prinsip perancangan yang digunakan adalah mekanistik, yang berarti perkerasan dianalisis menggunakan prinsip mekanik yang berhubungan dengan data beban kendaraan, tegangan, dan regangan. Untuk mendapat hasil yang optimal dibutuhkan beban kendaraan yang aktual dan parameter yang valid. Sedangkan pada metode AASHTO 1993, perancangan didasarkan pada serviceability, yaitu kemampuan perkerasan melayani repetisi beban kendaraan selama umur rencana.

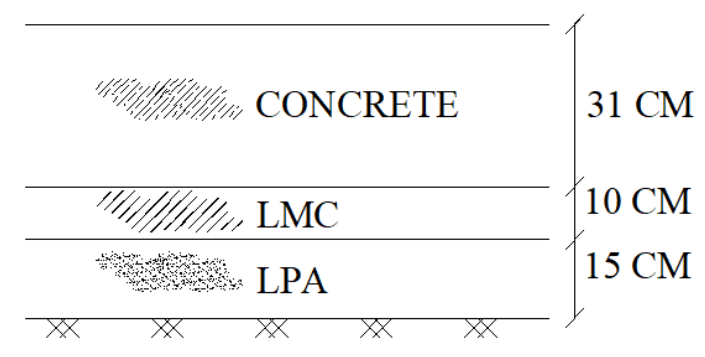

a. Hasil rancangan dengan Metode MDP-2017

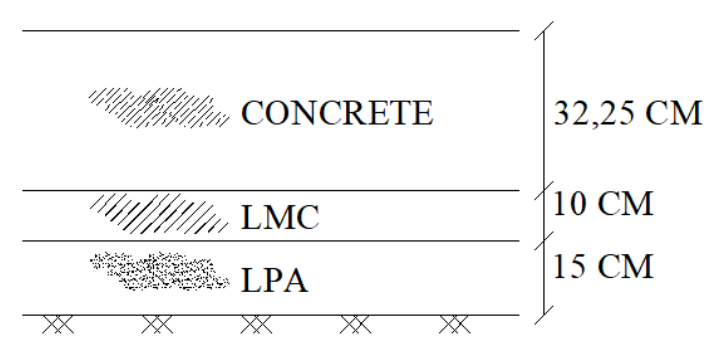

b. Hasil Rancangan dengan Metode AASHTO-1993

Gambar 1 Hasil Perancangan Tebal Perkerasan Jalan Lingkar Kota Wonogiri 


\section{KESIMPULAN}

Tebal pelat beton perkerasan jalan yang dihitung dengan menggunakan 2 metode yang berbeda, yaitu MDP 2017 dan AASHTO 1993, menghasilkan tebal pelat yang berbeda pula. Tebal pelat beton yang dihitung dengan metode MDP 2017 adalah $31 \mathrm{~cm}$, sedangkan tebal yang dihitung dengan metode AASHTO 1993 adalah 32,25 cm.

Perbedaan tebal yang diperoleh tidak begitu besar, karena MDP 2017 sendiri juga mengacu pada AASHTO 1993. Namun, karena MDP 2017 merupakan manual yang dikeluarkan oleh Direktorat Jenderal Bina Marga, Kementerian Pekerjaan Umum dan Perumahan Rakyat Republik Indonesia, parameter pada MDP 2017 ini lebih sesuai dengan kondisi Indonesia, dan sudah diklasifikasikan berdasarkan kondisi provinsi-provinsi di Indonesia.

\section{DAFTAR PUSTAKA}

American Association of State Highway and Transportation Officials (AASHTO). 1993. Guide for Design of Pavement Structures. Washington, DC.

Badan Pusat Penelitian dan Pengembangan. 2003. Perencanaan Perkerasan Jalan Beton Semen. Jakarta: Departemen Permukiman dan Prasarana Wilayah (Kimpraswil).

Direktorat Jenderal Bina Marga. 2017. Manual Desain Perkerasan Jalan. Kementerian Pekerjaan Umum dan Perumahan Rakyat. Jakarta.

Putri, R., Buchari, E., dan Pataras, M. 2014. Perencanaan Perkerasan Kaku dengan Menggunakan Beban Aktual Kendaraan. Palembang: Jurusan Teknik Sipil, Universitas Sriwijaya. 